\title{
Trst, Gorica in Istra: glasbena prepletanja
}

\author{
Luisa Antoni \\ Samostojna raziskovalka \\ Independent researcher
}

Po letu 1848, ko je večji del monarhije zajel izrazit val nacionalnega preporoda, so se v večjih mestih avstro-ogrske monarhije začela ustanavljati številna društva (kulturna, gledališka, zborovska, športna in umetniška), ki so bila del političnega in nacionalnega boja za obstoj in so se borila za uveljavljanje nacionalnih pravic. Trst, Gorica in Koper niso izvzeti iz tega nacionalnega vrvenja. Vsaka nacionalna skupina se je, po eni strani, primerjala s sosedom in je, po drugi, zatrjevala in utrjevala svojo različnost od matične domovine. V teh krajih se je italijansko govoreči Tržačan pomembno razlikoval od Italijana iz italijanske kraljevine (Tržačani so malce zaničevalno imenovali Italijane regnicoli, tj. tisti, ki so prihajali iz Regno d'Italia), Slovenec od Kranjca in Nemec od Avstrijca ali Nemca. Ob rednih vajah in sestankih so ta društva, ki so delovala predvsem v mestih, propagandno prirejala razne pobude, kot so bili koncerti, plesi in gledališke igre. $\mathrm{V}$ tem valu nacionalnega preporoda je imela glasba pomembno vlogo, ker je združevala posameznike, tako socialno kot ideološko. Tako živahno dogajanje je dalo zagon za ustanovitev ter razvojno povečanje javnih in zasebnih glasbenih ustanov.

S tem člankom želimo zajeti ves primorski prostor od Gorice in njenega zaledja do Trsta, Kopra, Pirana, Izole in deloma Istre (ta je še najmanj raziskana) in poskusiti oblikovati ali vsaj začeti širši pogled na prepleteno dogajanje. Na tem območju je pouk do leta 1918 potekal v treh jezikih: v nemščini (tj. uradni državni jezik), italijanščini in slovenščini. Zadnja dva 
jezika sta bila za nemško govorečo vlado medsebojno enakovredna (kot neuradna jezika). Po prvi svetovni vojni pa se je na tem območju zaradi političnih razmerij uveljavljala predvsem italijanščina. Preplet kultur je vsekakor ustvaril izjemno bogato iskrivo vzdušje: vsaka skupina se je hotela pred drugimi predstavljati v najboljši luči. Pravi izraz za tako dogajanje je civilno tekmovanje.

\section{Glasbeno šolanje}

Glasbeno šolanje je bilo možno $\mathrm{v}$ javnih in zasebnih šolskih institucijah. $\mathrm{V}$ Trstu in Kopru so delovale številne glasbene ustanove, ki so omogočale, da so šolarji pridobili osnovno glasbeno izobrazbo. Ker je bil Trst največje avstro-ogrsko pristanišče, je bila ponudba glasbenih šol na Tržaškem najbogatejša. Glasba je bila običajno del predmetnika državnih srednješolskih ustanov in pomemben del tako gimnazijskega kot učiteljskega študija. $\mathrm{Na}$ srednjih šolah so poučevali teoretične predmete, inštrumente in petje. Kdor je želel doseči srednješolsko stopnjo, je imel možnost, da se vpiše na dve ustanovi: na učiteljišče, kjer so se šolali bodoči učitelji, ali na gimnazijo.

\section{Glasbeno šolanje na javnih institucijah}

Na Primorskem so delovale štiri javne šole, ki so imele v svojem predmetniku glasbo, in sicer:

1. gimnazija v Kopru,

2. gimnazija v Pazinu,

3. moško italijansko in slovansko učiteljišče v Kopru,

4. goriško žensko učiteljišče.

Iz podatkov je razvidno, da so na koprski gimnaziji, ki so jo ustanovili leta 1814, poučevali glasbo, in sicer petje in violino (od leta 1838). Koprska gimnazija je bila na začetku italijansko-latinska (Coesareum Regium Gymnasium) in se je leta 1819 spremenila v latinsko-nemško, po nekajletnem premoru zaradi premajhnega števila vpisanih so jo meščani z lastnimi sredstvi znova odprli (Ginnasio Civico Justinopolitano) in leta 1852 je finančno breme šole prevzela država, pod pogojem, da se obdrži nemški jezik kot obvezni predmet. Ta šola je dala najvidnejše predstavnike istrske kulture in $\mathrm{v}$ njej so se šolali predvsem italijanski istrski domoljubi.

Vlasta Beltram v besedilu, ki je spremljalo katalog o glasbenem življenju slovenskih obalnih mest ob razstavi glasbil, navaja imena učiteljev 
glasbe na italijanski koprski gimnaziji, ti so bili Francesco Petronio (18631874), Giuseppe Czastka (1874-1883), Stefano Persoglia (1877-1878), Carlo Fuchs (1886), Giorgio Giorgieri (1891-1893), Antonio Decleva (1895-1897), Giovanni Luigi Sokoll (1897-1909), Roberto Catolla (1909-1910), Marcello Bombig (1913-1914) in Francesco Saverio de Tevini (1914-1919). Zanimiva je ugotovitev, da so nekatera imena navedena tudi v tržaški zgodovini glasbe, vsi pa so sočasno poučevali tudi na koprskem učiteljišču. Po letu 1919 v gimnazijskem predmetniku ni bilo več pouka glasbe.'

V Pazinu so nemško gimnazijo ustanovili leta 1836 , leta 1873 je prerasla v Staats-Obergymnasium zu Mitterburg, leta 1899 pa so odprli hrvaški oddelek. To je izzvalo protest italijanskih predstavnikov, zato so istega leta ustanovili še italijansko gimnazijo. Njen prvi ravnatelj je bil oče Luigija Dallapiccole Pio, ki je bil profesor latinščine in grščine. ${ }^{2}$ Pred razpadom Avstro-Ogrske so pazinsko gimnazijo zaprli in Dallapiccolovo družino deportirali v Gradec, ker so očeta sumili italijanskega iredentizma.

Na pazinski hrvaški gimnaziji, kjer so se šolali slovenski in hrvaški dijaki (med njimi tudi Danilo Švara), je bil pouk glasbe obvezni predmet. To potrjuje Saša Šantel, ki je na koprskem učiteljišču delal eno leto, zatem pa odšel na gimnazijo v Pazin in tam poučeval kar enajst let, do leta 1918. Njegova predmeta sta bila risanje in glasba. Takole se Šantel spominja svoje pazinske izkušnje:

Med višjegimnazijci sem izbral najboljše pevce, s katerimi smo peli moške zbore. Za cerkveno petje sem pa sestavil deški mešani zbor, ki se mi je posebno priljubil, vendar sem zanj moral prirediti ili komponirati vse komade sam. ${ }^{3}$

$\mathrm{Na}$ učiteljiščih so se šolali bodoči učitelji, ki so imeli skupaj z duhovništvom pomemben delež pri utrjevanju narodne zavesti. Učiteljišča so se ustanavljala po letu 1869 ob reorganizaciji avstro-ogrskega šolstva. Po letu 1882 je nova okrožnica še dodatno podkrepila prisotnost glasbe v šolskem kurikulumu. Podatke imamo o učiteljiščih v Ljubljani, Mariboru, Celovcu, Trstu, Kopru in Gorici. V Trstu je med letoma 1864 in 1875 delovalo italijansko moško učiteljišče, italijansko žensko učiteljišče je bilo aktivno med letoma 1872 in 1881 , v Gorici so leta 1870 ustanovili dvojezično učiteljišče

1 Vlasta Beltram, Musica Maestro! Glasbeno življenje v slovenskih obalnih mestih v 19. in 20. stoletju (Koper: Pokrajinski muzej Koper, 20o8), 37.

2 Mario Ruffini, L’opera di Luigi Dallapiccola (Milano: Suvini Zerboni, 1999), 25.

3 Saša Šantel, »Med barvami in glasbo«, v: Avgusta Šantel st., Avgusta Šantel ml., Saša Šantel, Življenje v lepi sobi (Ljubljana: Nova revija, 2006), 202. 
(italijansko-nemško in slovensko-nemško), leta 1875 pa so ga spremenili v izključno žensko učiteljišče. V Kopru je leta 1872 nastalo italijansko moško učiteljišče, leta 1875 pa je dobilo še slovenski in hrvaški oddelek. Z odlokom leta 1875 so moški slovenski učiteljišči prenesli iz Trsta in Gorice v Koper, kjer je bilo odslej edino moško učiteljišče za celotno avstrijsko Primorje. Leta 1907 so hrvaški del izselili v Kastav, slovenski del pa je bil leta 1909 premeščen v Gorico, kjer je tako postalo edino učiteljišče za slovenske bodoče učitelje. Premestitev koprskega oddelka v Gorico je bila posledica tritedenske dijaške stavke, v kateri sta imela levji delež Ivan Grbec in Srečko Kumar. ${ }^{4}$ Takole se dogajanja spominja Josip Ribičič:

Avstrijska oblast je varovala red in varčevala s priznavanjem nacionalnih pravic. Na ti šoli, kjer so bili slovenski fantje močni zaradi številčne večine, italijanski pa zaradi italijanskega značaja Kopra samega, so se prepletala trenja med študenti različne narodnosti, trenja med študenti in oblastjo dvoglavega orla, končno pa so $v$ zavest dijakov zadobivala jasne obrise tudi socialna trenja in narodnobuditeljske ideje, ki so iz bližnjega Trsta oplajale tudi koprsko obalo.

Iz Ribičičevega pričevanja izvemo, da je prav gotovo mali, mehki in sanjavi Grbec leta 1908 zasnoval in organiziral stavko dijakov z zahtevo po pouku $\mathrm{v}$ materinščini in vodil odposlanstvo dijakov $\mathrm{k}$ ravnatelju, da mu izroči spomenico in napove stavko, ter je bil med tistimi, ki so šli v Trst k dr. Rybařu in dr. Vilfanu iskat za koprske dijake politično podporo in zaslombo Edinosti.

Na koprskem učiteljišču je glasbeni pouk vključeval petje, igranje orgel, klavirja in violine, učni jezik za te predmete je bila nemščina, ki je bila tudi uradni jezik učiteljišča. Glasbo so poučevali profesorji, ki so učili tudi na gimnaziji. Ob državnih praznikih so učiteljiščniki pripravljali kulturno-glasbene programe. Na koprskem učiteljišču se je na slovenskem oddelku izšolalo več kot 400 dijakov, nekateri med njimi so se izključno posvetili glasbi: Ivan Kiferle (1856-1943), Hrabroslav Volarič (1863-1895), Ivan Kuret (1863-1914), Alojz Šonc (1872-1957), Rihard Orel (1881-1966), Franc Venturini (1882-1952), Srečko Kumar (1888-1954), Ivan Grbec (1889-1966) in Adolf Gröbming (1891-1969).

4 O dogajanju piše v članku: »Glasbeniki s koprskega učiteljišča«, v Cesarsko-kraljevo možko učiteljišče v Kopru: 1875-1909: Slovenski oddelek, ur. Mirjana Kontestabile Rovis, Jasna Čebron (Koper: Pokrajinski muzej, 2010), 64-71. 


\section{Društva in zasebno glasbeno šolanje}

Zasebno glasbeno šolanje je zacvetelo predvsem na razširjeni podlagi družbenega delovanja, saj so amaterji začutili potrebo po profesionalizaciji glasbene ponudbe. Sledi pregled po krajih, ki je le prvi korak za bolj poglobljene raziskave.

Na Koprskem: leta 1851 je Luigi Gravisi napisal članek Proposta di un regolamento per gli istituti di musica di Capodistria (Predlog pravil za glasbene ustanove $v$ Kopru), ki je marca in maja 1851 izšel v časopisu Il popolano dell'Istria. V njem Gravisi ugotavlja, da obstaja združenje amaterskih glasbenikov, vendar je ta skupina bolj primerna za nastopanje na prostem. Meni še, da je treba ustanoviti javno glasbeno ustanovo, ki bo poskrbela za potrebe mesta. Predlaga pravilnik in ustanovitev Filharmonične druž$b e$, ki bi nadzorovala glasbeno šolsko delovanje. Oblikovali bi se - pod filharmoničnim nadzorom - dve skupini: orkester in godba. V mapi, datirani 18. 4. 1853, je predlog pravil mestne glasbene šole. Pobudniški odbor (ki so ga sestavljali Giovanni de Manzini, Cristoforo Belli in Giovanni Genzo) je leta 1865 začel aktivnosti za ustanovitev družbe, statut pa je bil potrjen 21. 9. 1865. Učitelja glasbe so iskali $\mathrm{z}$ javnim razpisom in njegove zadolžitve so bile: skrbeti za glasbene priredbe, napisati vsaj tri avtorske skladbe na leto (za orkester, zbor in godbo) in kot organist spremljati na orglah praznične obrede. Imel je zadolžitve do filharmonične družbe (kot vodja orkestra in zbora), do občine (kot dirigent godbe) in cerkve (kot organist in dirigent pevskega zbora).

Od šestdesetih let so se v obalnih mestih ustanavljala filharmonična društva, poleg koprskega sta nastali še piranska Società filarmonico-drammatica (Filharmonična družba) in izolska Società filarmonica »Alieto" (Filharmonična družba Haliaetum). Leta 1906 so v Kopru ustanovili Glazbeno društvo Zvezda v Kopru, ki je vključevalo tako učiteljiščnike kot slovanske državne uslužbence in verjetno tudi tamburaško skupino. Med ustanovnimi člani je bil tudi Fran Gulič, violinist, ki se je šolal najprej pri Arturu Vramu v Trstu in nato pri Ševčíku v Pragi. Tako kot mnogim drugim mu je tržaška prefektura $\mathrm{z}$ dekretom leta 1930 ime poitalijančila $v$ Franco Gulli in tako se je predstavljal vse do smrti leta 1973. Življenje in delo Frana Guliča (Franca Gullija) še danes ni raziskano, čeprav je bil kot glasbeni pedagog dejaven pred prvo svetovno vojno in po njej. Pred razpadom Avstro-Ogrske je bil član orkestra tržaške Glasbene matice, kar potrjuje fo- 
tografija orkestra iz leta 1919 na strehi Narodnega doma. ${ }^{6}$ Po drugi svetovni vojni je obdržal italijanski priimek in je deloval izključno v italijanskih krogih.

Za nadaljevanje naše raziskave je zanimivo navesti seznam maestrov koprske filharmonične družbe do prve svetovne vojne: Giuseppe Czastka (1865-1874), Angelo Montanari (1874-1876), Pietro Bianchini (december 1876-november 1877), Gaetano Montanari (1877-1881?), Francesco Caretti (1883-1887), Giorgio Giorgieri (1888-marec 1893), Filippo Manara (18931900), Roberto Catolla (1902-1913?), Giuseppe Mariotti (april 1905-sredina 1912), Antonio Polento (1913-1915). ${ }^{7}$ Ta seznam bi bilo treba dodatno raziskati, saj se že na prvi pogled ugotavlja, da so nekateri od teh učiteljev glasbe sodelovali z raznimi glasbenimi ustanovami: tako na primer Giuseppe Czatka, ki je deloval na Goriškem, ali Filippo Manara in Roberto Catolla, ki sta bila po koprskem obdobju dejavna v Trstu.

Na Goriškem: tako kot v Kopru so se s podobnimi željami po profesionalizaciji glasbene ponudbe srečevali tudi v Gorici. Mestni veljaki so želeli usposobiti orkester, godbo in druge ansamble, da bi delovali v sklopu mesta. ${ }^{8}$ Leta 1823 so se predstavniki meščanstva zbrali in sestavili statut za Società degli amici filarmonici (Prijatelji Filharmonične družbe), na podlagi katerega so ustanovili glasbeno šolo, ki je delovala do leta 1830. Okrog leta 1835 je Antonio Gracco (1795-1881) začutil potrebo po novi glasbeni šoli, ki je kmalu propadla zaradi dolgov. Zatem je Čeh Procopio Frinta (1803-?) dal pobudo za ponovno ustanovitev mestne glasbene šole, ki je začela delovati 1. aprila 1842. Na njej sta poučevala Čeh Franz Xaver Kubik (1772-1848), ki je kot glavni učitelj deloval pod pokroviteljstvom grofov Attems, in Čeh Johann Schreiber (1801-1879) kot pomožni učitelj. Prisotnost čeških glasbenih učiteljev na Goriškem je bila zelo močna in je lahko predmet nadaljnjih raziskav.

6 Prim. Pavle Merkù, »Orkester Glasbene matice pred požigom Narodnega doma«, v 75 let Glasbene matice (Trst: Glasbena matica, 1986), 45 .

Seznam je objavljen v: Beltram, »Glasbeno življenje v slovenskih obalnih mestih v 19. in 20. stoletju«, 13. Naj opozorimo, da je pri imenu Catolle nastala napaka: ni Giuseppe, temveč Roberto.

Prim. Alessandro Arbo, Musicisti di frontiera (Gorica: Edizioni della Laguna, 1998), 93-99.

9 Njegovo ime je vpisano v več različicah: Kubick, Cubik, Chubick, Cubick. Po podatkih Cvetka Budkoviča je Kubik kot učitelj glasbe kandidiral na javni glasbeni šoli pri ljubljanski normalki. Prim. Cvetko Budkovič, Razvoj glasbenega šolstva na Slovenskem I (Ljubljana: Znanstveni inštitut Filozofske fakultete, 1992), 23. 
Nekoliko pozneje kot glasbeno šolanje v italijanščini se je na Goriškem pokazala tudi potreba po šolanju v slovenščini. Pri ustanavljanju samostojnega slovenskega glasbenega šolstva so se tako na Tržaškem kot na Goriškem zgledovali po ljubljanski Glasbeni matici. Čeprav je bil Trst pomembnejše in bolj razgibano mesto kot Gorica, je ta najprej ustanovila svojo šolo. Goričani so ustanovili svoje Pevsko in glasbeno društvo, v sklopu katerega je delovala tudi glasbena šola. Med ustanovnimi člani društva je bil tudi dr. Henrik Tuma, ki se dogajanja spominja takole:

$V$ Gorici je bil majhen pevski zbor v čitalnici pod vodstvom marljivega vadničnega učitelja Mercine. ${ }^{10}[. .$.$] Ker mi je boljše petje manj-$ kalo, sem nameraval ustanoviti $v$ Gorici reprezentativen pevski zbor s šolo. Dalj časa sem okleval zaradi učitelja Mercine, ki je s pravo ljubeznijo vzdrževal svoj mali čitalniški zbor. V začetku leta $190 o$ je bilo društvo končno ustanovljeno. Bil sem mu predsednik do leta 1908. Njegovo ustanovitev so poleg Mercine tudi moji politični nasprotniki smatrali za razdiranje njihove kulturne organizacije. Dolgo časa so prireditve Pevskega in glasbenega društva bojkotirali. [...] Prvi pevovodja je bil moj nekdanji sopevec v ljubljanski stolni cerkvi pod Foersterjem Franc Stelé, pozneje pevovodja Lire v Kamniku in sam izboren tenorist [...]. Žal smo Steleta prezgodaj izgubili. Po njegovem odhodu sem ustanovil tudi ženski zbor [...]. Za pevovodjo smo pridobili izšolanega konservatorista iz Prage Michla, ${ }^{\text {I }}$ ki je bil pozneje koncertni mojster pri Glasbeni matici v Ljubljani. Bil je izboren dirigent orkestra in solo fagotist, a manj dober zborovski dirigent. Pri društvu smo otvorili tudi pevsko in glasbeno šolo, ki je dajala izboren naraščaj. Člani pevskega zbora so bili med drugimi znani tenorist Rijavec ${ }^{\mathrm{I2}}$ in muzika Neffat in Bravničar. Pevsko in glasbeno društvo je bilo pač prvo za ljubljansko Glasbeno matico na Slovenskem. ${ }^{13}$

10 Ivan Mercina (1851-1940) je leta 1874 končal goriško gimnazijo in učiteljišče.

11 Josip Michl (1879-1959) je prišel v Gorico leta 1902 in prevzel vodstvo glasbene šole.

12 Joža (Josip) Rijavec (José Riavez) (1890-1959). Prim. Francka Slivnik, Ivo Svetina, ur., Josip Rijavec: slovenski tenorist mednarodnega slovesa (Ljubljana: Slovenski gledališki muzej, 2006). 
Leta 1904 je glasbena šola dobila nove prostore $\mathrm{v}$ Trgovskem domu, ${ }^{14}$ leta 1905 je priredila prvi večji koncert, ki se ga je udeležil tudi Matej Hubad, in 13. marca leta 1908 je Pevsko in glasbeno društvo uradno postalo podružnica ljubljanske Glasbene matice. ${ }^{\text {Is }}$

$\mathrm{Na}$ Tržaškem: v našem pregledu je Trst najpomembnejše mesto in najbolj raziskana glasbena zapuščina je italijanska. Pri pregledu seznama italijanskih in nemških glasbenih šol na Tržaškem ugotovimo, da je zdaleč največ ponudbe prav v Trstu, kjer sega zgodovina do leta 1560. To je leto, za katero hrani Stolna cerkev sv. Justa dokument, v katerem je zapisano, da je imel stolni Kapellmeister dolžnost, da uči mladino. ${ }^{16}$

Ker je gospodarski razvoj avstro-ogrskega pristanišča spodbudil demografsko rast, sta postala poznavanje glasbe in njeno izvajanje nujna elementa dobre meščanske vzgoje. Razvile so se številne šole petja, klavirja, violine in kitare. Te so bile namenjene sinovom in hčeram premožnih meščanskih družin. Občinska uprava je spodbujala glasbeno šolanje za sinove revnejših družin in prav te šole so omogočile, da se je ustanovil glasbeni konservatorij.

$\mathrm{Na}$ začetku 19. stoletja so $\mathrm{v}$ Trstu delovale številne zasebne glasbene šole, občinski Ricreatori in Salezijanski oratorij ter šola patra Giuseppeja Cervellinija (1750-pribl. 1826). Seznam vseh glasbenih šol v 19. stoletju je naslednji: pevska šola, ki je nastala za potrebe krajevnega opernega gledališča, v njej je učil Giuseppe Farinelli (1769-1836) in je delovala leta 1817, šola violinista Alessandra Scaramellija (1779-1862) je delovala med letoma 1822 in 1825, v njej so učili violino, violončelo, kontrabas, flavto, oboo, klarinet, kitaro, klavir, petje in kontrapunkt, šola Ferdinanda Karla Lickla (18031864), pianista, skladatelja in pedagoga, ki se je z Dunaja preselil v Trst (pri njem se je učila tudi Anna Weiss, mama Ferruccia Busonija), šola je delovala leta 1830. Med letoma 1838 in 1843 je Eduard Jaell (pribl. 1783-1849) ustanovil šolo za violino, violončelo in klavir. Med letoma 1843 in 1915 je bila aktivna šola za zborovsko petje za mlade, ki so živeli v Inštitutu za uboge. Šolo, ki je delovala po metodi Wilhema, sta vodila Francesco Dall‘Ongaro

14 Tržaški Narodni dom in goriški Trgovski dom je zgradil arhitekt Max Fabiani, oba domova sta bila uničena $v$ fašističnem požigu, tržaški 1920, goriški 1926. V goriškem požigu so bile uničene originalne skladbe Emila Komela in Joška Jakončiča.

15 Tatjana Gregorič Vuga, »Glasbene povezave na Goriškem ali razklani cvet«, v Nova Gorica - Gorica: izzivi in možnosti sobivanja: zbornik, ur. Jan Zoltan (Nova Gorica: Mestna občina, 1997), 127.

16 La cappella civica di San Giusto, 450 anni di musica a Trieste (1538-1988) (Trst: Cappella Civica 450, 1989), 15. 
(1808-1873) in Francesco Sinico (1810-1865). Uspeh tega poučevanja je prispeval k temu, da se je projekt razširil tudi na druge osnovne šole. Pouk je bil prvotno v nemščini in je polagoma prešel v italijanščino.

Med letoma 1849 in 1915 je delovala šola akademskega in cerkvenega petja, ki jo je vodil Luigi Ricci (1805-1859). Leta 1858 so ustanovili glasbeno društvo, ki ga je vodil violinist Julius Heller (1839-1901), leta 1859 pa se je društvo preimenovalo v Schillerverein. Isto leto je delovala pevska šola, ki jo je vodil Francesco Giacomo Zingherle (1822-1901). Med letoma 1863 in 1869 je Luigi Vincenzo Sandri (o njem ni biografskih podatkov) vodil svojo kompozicijsko šolo. Arturo Vram (186o-1938), ki je učil po Ševčíkovi violinski metodi, je od leta 1887 vodil glasbeni licej, ki je štel približno 100 učencev. V teh letih so bili dejavni še Antonio Rossetti s svojo šolo flavte, Ernesto Luzzatto (1865-1939) in Emilio Russi (1876-1965), vsak s svojo klavirsko šolo. Leta 1924 je Franco Gulli (Fran Gulič) ustanovil Tržaško glasbeno akademijo. Naj spomnimo, da je bil Franco Gulli tudi med ustanovnimi člani društva Zvezda v Kopru.

V Evropi in takratnem civiliziranem svetu je bil Trst napredno politično in kulturno ozaveščeno mesto. V mesto se ni priseljevala le nekvalificirana delovna sila, temveč tudi intelektualci in umetniki. Za Trst se je leta 1904 odločil James Joyce, štiri leta pozneje tudi sveže poročeni slovenski skladatelj in publicist Emil Adamič z ženo. Skratka mesto, ki je bilo takrat najpomembnejše avstro-ogrsko pristanišče, je cvetelo v gospodarskem in kulturnem pogledu. Razvilo se je živahno glasbeno življenje z bogato koncertno dejavnostjo solistov, dirigentov, instrumentalnih skupin, zborov, godb in telovadnih društev. Vsa ta združenja so bila za vse tri narodnostne skupine pomemben agregacijski dejavnik.

Veliko je zapisov o t. i. Musicieren, o glasbenih srečanjih, na katerih so se ob profesionalcih izkazali tudi domači člani uglednih družin (npr. doma pri Venezianijevih, tj. doma pri Italu Svevu, pri baronu Rodolfu Parisiju, pri družinah Doria, Ralli, Hummel, Bazzoni, Glanzman, Brunner, Oblasser, Pollitzer, Schott in Randegger). Italo Svevo in vsa njegova družina so doma muzicirali ob prisotnosti prijateljev, med katerimi je bil občasno tudi James Joyce. Italijanski filozof Gillo Dorfles se takole spominja:

Si vstopal $v$ nekoliko temačni vhod, komplicirano razdeljen, $v$ katerem je bilo vedno polno plaščev in ogrinjal. Različna vrata so potem vodila $v$ številne majhne dvorane in $v$ večje dvorane za sprejeme. Cenen okus, ki je bil tako zelo tipično findesiklovsko avstrijski, 
se je razlegal po tistih velikih dvoranah, $v$ katerih je bilo svetlo in impozantno pohištvo. Velik klavir je bil v glasbeni dvorani. ${ }^{17}$

Družinski člani so sprejemali goste v svojih sobah in se ločeno družili, dokler jih ni s posebnim zvoncem sklicala gospa Olga, Svevova tašča, in tako oznanila, da se začenja glasbeni del. V veliki sobi so igrali razni profesionalci (predvsem priljubljena sta bila Cesare Barison (1887-1974) in Tržaški kvartet), takoj zatem pa so nastopali še družinski člani, med katerimi je predvsem izstopal Bruno. Tudi Italo Svevo je večkrat nastopal kot druga violina v kvartetu, v katerem so sodelovali še Silvio Höberth (prva violina), Lionello Levi (viola) in Oscar Danese (violončelo). ${ }^{18}$ Sporedi so bili precej umirjeni: Schubert, Schumann, Wolf, vse seveda v nemščini za pevke, in še veliko Mozarta, Beethovna in Brahmsa za pianiste in kvartet. Stalni gost je bil Tržaški kvartet, tj. godalni kvartet Avgusta Jankovicha. Eden pomembnejših glasbenikov tega obdobja je bil Avgust Jancovich (Jankovich, Iancovich). Bil je nedvomno izjemen glasbenik, ki spada isto $v$ glasbeno družino kot pevki Mileva Pertot in pred kratkim preminula Nora Jancovich. Avgust ali Augusto Jancovich se je rodil v Trstu 26. (ali 28.) februarja 1878, njegov oče Stefano Jancovich je bil hornist, ki se je leta 1870 (ali 1871) v Trst priselil iz Istanbula, da bi delal kot prvi rog tržaškega orkestra. Avgust je študiral pri Albertu Castelliju (1851-1912) in začel nastopati že zelo zgodaj. V prvih desetletjih 2o. stoletja je bil nedvomno najboljši tržaški violinist, ki je žel priznanja številnih skladateljev, med drugim pri Riccardu Zandonaiu in Richardu Straussu. Ta je menda postavil kot pogoj za tržaško izvedbo svojih Tod und Verklärung in Don Juan, da je orkester pripravil Jancovich. Domnevamo, da je bil prva violina, ko je tržaškemu orkestru dirigiral Gustav Mahler. Deloval je kot solist, predvsem pa v komornih zasedbah, kot sta njegov Tržaški kvartet in duo s pianistom Eusebiem Currelichem. Kritike opisujejo njegovo igranje kot toplo, domiselno, tehnično dovršeno. Po prvi svetovni vojni je bil prva violina $v$ tržaškem gledališču in pedagog na tržaškem konservatoriju. Oktobra 1918 je nastopil kot Konzertmeister dunajskega Konzertvereina. Njegov kvartet je nastal po zgledu Hellerjevega in spodbudno vplival na razvoj mestnega življenja.

Med gosti Venezianijevih je bil tudi Edoardo Weiss, rojen kot meščan Avstro-Ogrske, prvi, ki se je učil neposredno pri Freudu in ki je moral leta 1939 zaradi protijudovskih zakonov zapustiti Italijo. Leta 1931 je šel iz Trsta

17 Gillo Dorfles, »A Trieste è crollata una villa«, v La Letteratura, 27. 4. 1946.

18 Giuseppe Radole, Le scuole musicali a Trieste e il Conservatorio »G. Tartini (Trst: Edizioni Italo Svevo, 1988), 31. 
$\mathrm{v}$ Rim in leto pozneje je $\mathrm{z}$ rimskimi sodelavci spodbudil delovanje italijanske psihoanalitične družbe. Weiss je bil stalni gost pri Venezianijevih in ob duševni bolezni mladega Bruna, najbolj glasbeno nadarjenega otroka družine Veneziani, so prav njega vprašali za nasvet in se skupaj odločili za pregled na Dunaju pri Freudu. Bruno je bil umetniška duša, zanimale so ga vzhodne filozofije in seveda glasba. Nagnjen je bil k istospolnim odnosom in jemanju mamil.

\section{Tržaški konservatorij}

Posebno obravnavo si zasluži ustanovitev tržaškega konservatorija v državi, ki je bila še vedno avstro-ogrsko cesarstvo. Ob koncu 19. stoletja je italijansko meščanstvo $\mathrm{v}$ Trstu hotelo postaviti javni glasbeni konservatorij, ki bi mladini omogočal, da se akademsko izobrazi za številne inštrumente. Sočasno sta se oblikovali dve prošnji, ki sta ju pripravila Roberto Catolla in Filippo Manara. Zelo zanimivo je, da sta oba pred tem sodelovala v Kopru kot glasbena učitelja. Roberto Catolla je bil Tržačan, Filippo Manara pa je bil doma iz Imole in je pred Koprom poučeval v Splitu in Novem gradu. Leta 1900 se je preselil v Trst, kjer je postal med drugim tudi glasbeni kritik krajevnega časopisa Il Piccolo. Tako Catolla kot Manara sta poslala prošnjo na Dunaj, da bi lahko odprla glasbeni licej. Manara je pripravil učni načrt po zgledu Bologne (kjer je tudi sam diplomiral) in Dunaja. 9. januarja 1902 je poslal prošnjo na tržaško vladno namestništvo in čakal na odgovor do 15. decembra.

Manaru so prošnjo zavrnili, ker ne on ne nekateri njegovi profesorji niso imeli avstrijskega državljanstva, Catolli pa so jo odobrili, čeprav je v šolskem statutu jasno pisalo, da ima "glasbeni licej $v$ Trstu kot učni jezik italijanščino in je tako prvi institut te vrste v kraljestvu« ${ }^{19}{ }^{1} \mathrm{Za}$ Manarov glasbeni licej se je angažiral odv. Felice Venezian, ki je imel podporo poslancev Attilia Hortisa, Felicea Bennatia in Leopolda Mauronerja. Dunajska vlada je ob ponovni prošnji dovolila ustanovitev le pod pogojem, da so bodoči uslužbenci avstrijski državljani. Šolo so poimenovali (ob dovoljenju piranske občine) po Giuseppeju Tartiniju, ker so mnogim ostala v spominu množična odmevna praznovanja ob postavitvi Tartinijevega kipa v Piranu. Kmalu je Manarov licej prešel od začetnih 182 vpisanih k skoraj 30o. Po slabem letu so se nekateri profesorji odločili, da ustanovijo še eno glasbeno šolo, ki se je pozneje preimenovala v Konservatorij Giuseppe Verdi. 15. februarja 1904 so pridobili dovoljenje, da odprejo novo šolo, ta se je imenovala glasbeni

19 Radole, Le scuole musicali a Trieste, 36. 
konservatorij iz Trsta (Conservatorio musicale di Trieste). Vodstvo šole so zaupali Gialdinu Gialdiniju (1843-1919), skladatelju in dirigentu, ki se je šolal v Firencah. Po vojni in Gialdinijevi smrti je šolo vodil hornist in gledališki impresarij Olimpio Lovrich (?-1928), ki se je rodil v Dalmaciji in je bil ded slavnega italijanskega režiserja Giorgia Strehlerja. Lovrich je povabil k sodelovanju Giana Giacoma Manzutta (1861-1933), glasbenega kritika, rojenega v Umagu, ki je študiral na Dunaju in v Bologni.

Po Manzuttovem odhodu je vodstvo šole prevzel Federico Bugamelli (1876-1949), ki se je najprej poskušal uveljaviti v Ukrajini, a je po revoluciji zbežal z družino in pristal v Trstu. 15. julija 1932 sta se Verdi in Tartini združila $\mathrm{v}$ Ateneo musicale triestino, ki se je pozneje preimenoval v Liceo musicale triestino in šele leta 1953 pod zavezniško upravo res postal državni konservatorij. ${ }^{20}$

\section{Tržaška Glasbena matica}

$\mathrm{V}$ istem obdobju kot italijansko meščanstvo je tudi slovensko oziroma slavljansko ${ }^{21}$ meščanstvo ustanavljalo svojo glasbeno šolo in dramatično društvo, ki sta imela svoj sedež v Narodnem domu. Leta 1908 je bil Vasilij Mirk naključno pri nastajanju zbora, iz katerega se je pozneje, ob organizacijskem spodbujanju Karla Mahkote (1883-1951), ki je od leta 1908 do leta 1919 učil v Trstu, razvila tržaška podružnica Glasbene matice. Mirk izčrpno opisuje dogajanje:

Vladalo je mrtvilo, ki ga je prekinila le kakšna manjša skupina pevcev. Nima pomena razpravljati o vzrokih. [...] Vesti o pevskih uspehih in napredovanju Glasbene matice $v$ Ljubljani in Pevskega in glasbenega društva $v$ Gorici (vodja Josip Michl), novi duh, ki so ga tiho, a učinkovito širili »Novi akordi«, ter narodna samozavest, $k i$ se je bila medtem ukoreninila pri tržaških Slovencih, so vzdramili nekatere bivše pevce Slovanskega pevskega društva, ki so bili tudi člani tržaškega Sokola. Zbudila se jim je želja po petju in skupno $z$ nekaterimi novimi Sokoli - pevci so sklenili ustanoviti pevski odsek $v$ okviru Sokola. Bilo je ravno konec poletja 1908, ko so me naprosili, naj jih naučim par moških zborov za neko sokolovsko prireditev. [...] Slučajno pa je bil tedaj imenovan za učitelja $v$ Trstu Karel status državne šole. 
Mahkota, ki je prevzel vodstvo sokolovskega pevskega zbora in ga tekom prvega leta razširil v mešani zbor. ${ }^{22}$

Ta podatek je potrdil tudi Fortunat Mikuletič, ki je zapisal, da

se je leta 1908 osnoval moški zbor pri tržaškem Sokolu pod vodstvom skladatelja Vasilija Mirka. Kmalu po prvem nastopu tega zbora pa je moral Mirk, ki je bil še študent, oditi na svoje študije v Gradec. ${ }^{23}$

29. oktobra 1909 se je občnega zbora Glasbene matice udeležil tudi Matej Hubad. V teh letih je bilo živahno in polno kulturnega vrenja tudi v slovenskih društvih. $\mathrm{V}$ tem mestu so zrastli glasbeniki, ki so prispevali pomemben delež k razvoju slovenske in češke glasbe (tako npr. Mirko Polič in Vasilij Mirk, Josip Mandić je po razpadu Avstro-Ogrske odšel na Češko). V tako živo kulturno vrvenje se je Emil Adamič, ki se je tja priselil, vključil brez velikih težav. Njegovo delovanje in njegovo poročanje za razne slovenske revije sta pokrila Trst in njegovo predmestje, očitno mu številna premikanja po mestu in zunaj mesta niso delala velikih preglavic. Adamičeva vdova je veliko let pozneje svojim vnukom pripovedovala, kako je bil takrat Trst živo mesto številnih kultur, za mladi par polno izzivov. ${ }^{24}$ Posebno poglavje Adamičevega tržaškega obdobja je učenje na tržaškem konservatoriju: tedaj so se na tržaški glasbeni šoli učili tudi Mirko Polič, Srečko Kumar in Vasilij Mirk. Škerjanc je zapisal, da je Adamič v tržaški konservatorij vstopil 1. septembra 1911. Leta 1951 je njegov prijatelj in nekdanji kolega Adolf Gröbming tako zapisal:

Prvi večji preokret v skladateljski tehniki kažejo njegove skladbe iz tržaške dobe. V tržaško okolje se je uvedel z razposajenim Vasovalcem, ki ima prostejšo deklamacijo in večjo razgibanost $v$ harmoniki in melodiki, kakor njegove prve skladbe. $V$ drugih delih iz te dobe (Ecce dolor, Kregata se baba in devojka, Bela breza, Mlad junak idr.) se pozna čimdalje bolj blagodejen vpliv njegovega študija

22 Vasilij Mirk, "Tržaška Glasbena Matica«, Zbori 5, št. 1 (1929): 4, http://www.dlib. si/?URN=URN:NBN:SI:DOC-GC6ZUK5 5 .

23 Odvetnik Mikuletič (1888-1965) je bil podobno kot Mirk član Akademskega društva Balkan in ga je po drugi svetovni vojni poskušal znova obuditi. Ob petdesetletnici društva je uredil, izdal in verjetno tudi sam napisal spominsko brošuro 50 let Slovenskega akademskega društva Balkan v Trstu (Trst, 1957). Po drugi svetovni vojni je bil predsednik Glasbene matice.

24 Ustno pričevanje Adamičevega vnuka dr. Milana Orožna Adamiča (1946-2018), Ljubljana, 20. 11. 2003. 
na tržaškem konservatoriju in kot izrazno sredstvo se pridruži dotlej čisto harmoničnemu stavku kontrapunkt. ${ }^{25}$

Iz tega Adamičevega tržaškega študija sta gotovo izšli dve deli: prva je skladba Preludio di una commedia za veliki orkester, rokopis je v knjižnici tržaškega konservatorija, drugo delo, ki pa je, tako se zdi, izgubljeno, je skupina štirih sonat za violino in klavir. Omenjata jih tako Škerjanc kot Mantuani. Ta je leta 1928 ob skladateljevi 5o. obletnici napisal, da je leta 1914 Adamič napisal štiri sonate za klavir, ki so prestale strog pregled Gialdina Gialdinija, takratnega ravnatelja konservatorija, ta jih je uvrstil na program javnih produkcij. ${ }^{26}$ Po pričevanjih se je Adamič vpisal v 4. letnik kompozicije, študiral pa je z Antoniom Zampierijem, tako kot tudi Mirko Polič, klavir pa je študiral pri Fabiu Riminiju. ${ }^{27}$

Slovenci so imeli v prostorih Narodnega doma glasbeno gledališče, predvsem z operetnim repertoarjem, uprizarjali pa so tudi tako zahtevna dela, kot so "Janko in Metka" Engelberta Humperdincka, "Nikola Šubić Zrinski« Ivana Zajca, Parmovo »Ksenijo«, celo »Prodano nevesto « in »Čarostrelca« Carla Marie von Webra. Eden od poznejših pomembnejših dirigentov jugoslovanskih odrov, rojenih v Trstu, Mirko Polič ${ }^{28}$ je v teh letih veliko sodeloval z Leonom Dragutinovićem prav pri pripravah teh uprizoritev. Pred premiero opere »Madame Butterfly« jo je založnik tik pred predstavo prepovedal, češ da se v italijanskem Trstu italijanske opere lahko pojejo samo v italijanščini. ${ }^{29}$ Prvo poročilo o dogodku, ki ga je časnik Edinost pozneje označil kot kulturni škandal, se je v javnosti pojavilo 5. oktobra 1913:

Opera je študirala in pripravila Puccinijevo "Madame Butterfly« (Die kleine Schmetterling; Metuljček) in jo je tudi popolnoma naštudirala in pripravila za nocoj, da v njej predstavi občinstvu

Adolf Gröbming, »Spominu Emila Adamiča«, Naši zbori, št. 6 (1951): 21-22.

Obe skladbi naj bi doživeli praizvedbo na konservatoriju. Josip Mantuani, Emil Adamič, prigodom pedesete godišnjice njegova narodjenja (s. 1. n., 1928), 3.

Rojčev podatek, da se je učil klavir s Pio Rimini, ne drži, saj je edini Rimini v takratnem učiteljskem zboru po imenu Fabio. Aleksander Rojc, Cultura musicale degli Sloveni a Trieste (Trst: ZTT, 1978), 49.

Skladatelj in dirigent Mirko Polič se je rodil 3. junija $1890 \mathrm{v}$ Trstu, oče je bil doma iz Karlobaga, mati pa je bila tržaška Slovenka. Leta 1908 je maturiral in se odpravil v Prago študirat pravo, kmalu se je vrnil v Trst, kjer je leta 1913 končal šolanje na tržaškem konservatoriju Verdi. Ob tem, da je vodil zbore, je leta 1911 postal kapelnik Narodnega gledališča v Trstu.

O tem ni ostalo uradnih dokumentov, so pa časopisni članki v Edinosti. 
svoje novo angažirane operne sile. $V$ istem času, ko se je začela opera študirati, se je tudi obrnila intendanca na tukajšnjega zastopnika založniške firme Ricordi v Milanu za dovoljenje za uprizoritev in pozneje tudi direktno na firmo samo, da bi se gotovo izognila vsaki nepriliki, a vendar trdno pričakujoč, da dobi to dovoljenje popolnoma gotovo, kot nekaj samoobsebi umljivega - saj taka dovoljenja dajejo $z$ veseljem vsa nemška založništva, ki še ne štejejo 2oooletne kulture. V našem slučaju pa se je zgodilo drugače: Definitivno prepoved nam je tukajšnje zastopništvo dalo šele včeraj pozno popoldne in je bil dotični gospod zastopnik tudi toliko odkrit, da je povedal, da leži vzrok prepovedi v tem, da je Trst italijansko mesto in se vsled tega opera na teh »italijanskih" tleh ne sme peti v slovenskem jeziku.

Kaj naj rečemo na to? Intendanca je storila svoje ter določila, da se uprizori drugič velika Tucićeva drama »Golgota«. Kaj pa naj stori slovensko občinstvo? Kako naj odgovori ta $v$ teptani rod na tako šikaniranje »kulturnega« naroda? Naj polni še nadalje italijanske šantane, naj vsled namišljenega razočaranja še naprej kar zija nad uprizoritvami $v$ italijanskih gledališčih in še naprej prezira in zabavlja ter omalovažuje naše narodno gledališče, ki se vsled težkih žrtev nekaterih tako lepo razvija in ima v svojem letošnjem programu že stalno opero?

Vodstvo gledališča čaka odgovor pri nocojšnji predstavi, da vidi, koliko je še samozavestnega Slovenstva v Trstu, ki se ne da teptati od italijanskega šovinizma, ki dokaže, da pozna in spoštuje tudi lastno kulturo, da živi in se razvija samostojno - četudi se vsi zapahi magari 3 oooletne italijanske kulture pred njim zapro. ${ }^{\circ}$

Iz teh besed je jasno, da je vzdušje v mestu postajalo vse bolj napeto, čeprav je fašizem uradno nastopil skoraj desetletje pozneje. Tako je Alojz Rebula, Prešernov nagrajenec in nekdanji profesor na klasičnem liceju v Trstu, opisal to obdobje:

Za tistega pol milijona Slovanov, v glavnem Slovencev, ki so se po razpadu Avstro-Ogrske znašli v sklopu italijanske kraljevine, so bila dvajseta leta praktično v celoti kulturno genocidna, saj je požig hotela Balkan $v$ Trstu, ta uvertura $v$ njihovo nacionalno tragedijo, datiran že v predfašistično leto 1920. Nad slovenskimi organi-

30 Anon., »Slovensko gledališče v Trstu«. Edinost 38, št. 276 (5. oktober 1913): 10-11, http://www.dlib.si/?URN=URN:NBN:SI:doc-FGTE6RMG. 
zacijami, šolstvom, tiskom, cvetoče ljudsko prosveto se od Alp do morja zgrinja noč, ki bo v tridesetih letih zbrisala slovenščino tudi z nagrobnikov. ${ }^{31}$

Po letu 1920 in sežigih Narodnega in Trgovskega doma v Trstu in Gorici, kjer sta glasbeni šoli izgubili imetje in arhive, so začeli fašistični pritiski naraščati. Fašističnemu dvajsetletju je Glasbena matica kljubovala in premaknila pouk $\mathrm{v}$ zasebne domove in na razne društvene sedeže. Leta 1920 je Srečko Kumar (1888-1954) ustanovil zasebno glasbeno šolo v Škednju pri Trstu. ${ }^{32} \mathrm{~V}$ istem obdobju sta $\mathrm{z}$ Ivanom Grbcem (1889-1966) prirejala otroške igre z glasbo. Leta 1922 je na Tržaškem nastal pevski zbor Zveze jugoslovanskih učiteljskih društev $v$ Italiji (UPZ). Ustanovil ga je Kumar, ob podpori Josipa Ribičiča in Ivana Grbca, nekdanjih sošolcev na koprskem učiteljišču. Zbor je štel približno 120 članov in je do leta 1926 koncertiral tudi po Italiji. $\mathrm{Z}$ njimi je kot solist nastopal tudi že omenjeni tenorist mednarodnega slovesa Josip Rijavec. V Trstu je bila leta 1927 Glasbena matica razpuščena. V teh letih je vladal kulturni in glasbeni molk za vse tiste, ki so govorili drugačen jezik od italijanščine, kdor je želel nadaljevati, je moral pozabiti na slovenščino in se odreči večkulturni realnosti.

\section{Sklep}

Za boljše razumevanje zgodovinsko-glasbenih dogajanj Trsta in Gorice je nujno, da ju obravnavamo kombinirano in upoštevamo močne vezi, ki sta jih imela $\mathrm{z}$ območjem notranje Slovenije, $\mathrm{z}$ avstrijsko vlado in med njimi ter vezi, ki sta jih imela Trst in Gorica s svojim naravnim zaledjem. Predvsem pa je pomembno, da sestavljamo celostno podobo, ki pri tržaški stvarnosti upošteva tudi del Istre, tj. to, kar je bilo tržaško naravno zaledje, dokler se ni državna meja dokončno ustalila. Največja težava, s katero se srečujejo tisti, ki obravnavajo zgodovino glasbe v Trstu, Gorici, Kopru, Izoli in Piranu, je, da ležijo ta mesta v državah, ki ju danes loči meja, torej na meji med Italijo in Slovenijo, na območju, ki je bil pred tem enoten, a je danes ločen. Med letoma 1918 - ko je avstro-ogrska država razpadla - in 1954 - ko se je meja med conama A in B dokončno ustalila - se je državna meja premikala z italijansko in nemško zasedbo slovenskega ozemlja in partizansko osvoboditvijo Trsta. Po letu 1954 je bilo to ozemlje na splošno razdeljeno na

31 Alojz Rebula, »Evropski moment v Gorici 1921: in memoriam Alojzij Res«, v La Mitteleuropa negli anni Venti: Culturà e società, ur. Quirino Principe (Videm: Istituto per gli incontri culturali mitteleuropei, atti del XXIII convegno, 1992), 245. 
dva dela. Čeprav se je prisotnost meje danes ublažila, potekajo zgodovinska raziskovanja glasbe v teh dveh državah (predvsem na italijanski strani) po vzporednih in vsekakor nestičnih tirnicah. Koper, Piran in Izola so mesta ob Jadranskem morju in so s Trstom skupno dihala do leta 1918 in deloma tudi potem. Šele leta 1954 se je meja dokončno ustalila in se globoko zarezala v družinsko in družbeno življenje ozemlje ter v zgodovino mest. Izseljevanje istrskih optantov iz slovenskih obalnih mest je dodatno razpršilo že tako razcepljeno dogajanje in ustvarilo v mestih, od koder so odšli, kulturno praznino, njihov prihod $\mathrm{v}$ Trst pa je globoko preobrazil mestno tkivo in ga prepletel $\mathrm{z}$ nestrpnostjo do drugače govorečih.

Vsekakor sklenemo z ugotovitvijo, da še vedno nimamo prave podobe o tem, kar se je v teh krajih dogajalo: nujno je, da ta prostor - to, kar danes razumemo pod imenom Primorska - obravnavamo kot enoten prostor. Celotna Primorska in njeno glavno mesto Trst sta se ponujala kot zanimiva delavnica medkulturnosti in večkulturnosti. Tako kot italijanski zagnani iredentisti bi lahko tudi slovensko tržaško meščanstvo doseglo ustanovitev slovanskega ali slovenskega javnega glasbenega šolanja, če ne bi fašistično stopnjevanje terorja presekalo vseh možnih glasbenih poti za neitalijansko govoreče glasbenike: večina intelektualcev se je izselila v Jugoslavijo in mnogi se niso več vrnili niti po drugi svetovni vojni, čeprav so izrazili to željo (npr. Vasilij Mirk). Tisti, ki so tu ostali, so se morali odločiti ali za neupirajočo se asimilacijo (npr. Franco Gulli) ali za nemi upor (npr. Josip Merkù, oče skladatelja in intelektualca, Prešernovega nagrajenca Pavleta Merkuja).

Čeprav je že desetletja predvidena slovenska sekcija tržaškega konservatorija, je še vedno samo na papirju in je verjetno danes že zastarela zahteva, saj imajo mladi glasbeniki danes možnost za šolanje ali izpopolnjevanje v Ljubljani in ne nazadnje po vsem svetu.

\section{Bibliografija}

Anon. »Slovensko gledališče v Trstu«. Edinost 38, št. 276 (5. oktober 1913): 10-11. http://www.dlib.si/?URN=URN:NBN:SI:doc-FGTE6RMG.

Antoni, Luisa. »Mirk v Trstu«. V Mirkov zbornik, ur. Edo Škulj, 47-67. Ljubljana: Družina, 2003.

Antoni, Luisa. Pogovor z Adamičevim vnukom, dr. Milanom Orožnom Adamičem. Ljubljana, 20. 11. 2003.

Antoni, Luisa. »Adamičeva tržaška leta«. V Adamičev zbornik, ur. Edo Škulj, 2539. Ljubljana: Akademija za glasbo, 2004. 
Antoni, Luisa. „Glasbeniki s koprskega učiteljišča«. V Cesarsko-kraljevo možko učiteljišče v Kopru: 1875-1909: Slovenski oddelek, ur. Mirjana Kontestabile Rovis, Jasna Čebron, 64-71. Koper: Pokrajinski muzej, 2010.

Antoni, Luisa. »Raznolikost in bogastvo glasbenega šolanja na Primorskem«. V Javno glasbeno šolstvo na Slovenskem, 25. zvezek. Ljubljana: Glasbenopedagoški zbornik Akademije za glasbo, 2016.

Arbo, Alessandro. Musicisti di frontiera. Gorica: Edizioni della Laguna, 1998.

Barison, Cesare. Trieste città musicalissima. Trst: Edizioni Lint, 1976.

Beltram, Vlasta. Musica Maestro! Glasbeno življenje v slovenskih obalnih mestih v 19. in 2o. stoletju. Koper: Pokrajinski muzej Koper, 2008.

Budkovič, Cvetko. Razvoj glasbenega šolstva na Slovenskem I. Ljubljana: Znanstveni inštitut Filozofske fakultete, 1992.

Buffulini, Aristide, Bianca Maria Favetta, Laura Ruaro Loseri. Testimonianze sull'educazione musicale nella vita di Trieste. Trst: Istituto per l'Enciclopedia del Friuli Venezia giulia, 1979.

Demšar, Gojmir. 90 let Glasbene matice Trst. Trst: Glasbena matica, 1999.

Dorfles, Gillo. »A Trieste è crollata una villa«. V La Letteratura, rivista di lettere e arte contemporanea, 27. 4. 1946.

Gregorič Vuga, Tatjana. »Glasbene povezave na Goriškem ali razklani cvet«. V Nova Gorica - Gorica: izzivi in možnosti sobivanja: zbornik, ur. Jan Zoltan. Nova Gorica: Mestna občina, 1997.

Gröbmig, Adolf. »Spominu Emila Adamiča«. Naši zbori, št. 6 (1951): 21-22.

Konestabile Rovis, Mirjana, Jasna Čebron, ur. Cesarsko-kraljevo možko učiteljišče v Kopru: 1875-19o9: Slovenski oddelek. Koper: Pokrajinski muzej, 2010.

Kravos, Marko et. al. Narodni dom v Trstu 1904-1920. Trst: Narodna in študijska knjižnica, 1995.

La cappella civica di San Giusto, 450 anni di musica a Trieste (1538-1988). Trst: Cappella Civica 450, 1989.

Levi, Vito. La vita musicale a Trieste, cronache di un cinquantennio. Milano: All'insegna del pesce d'oro, 1968.

Mantuani, Josip. Emil Adamič, prigodom pedesete godišnjice njegova narodjenja. S. 1. n., 1928.

Merkù, Pavle. »Orkester Glasbene matice pred požigom Narodnega doma«. V 75 let Glasbene matice, 44-45. Trst: Glasbena matica, 1986.

Mikuletič, Fortunat. 50 let Slovenskega akademskega društva Balkan v Trstu. Trst: 1957.

Mirk, Vasilij. »Tržaška Glasbena Matica«. Zbori 5, št. 1 (1929): 4-5. http://www.dlib. si/?URN=URN:NBN:SI:DOC-GC6ZUK5U. 
Mirk, Vasilij. »Tržaška Glasbena Matica«. Zbori 5, št. 2 (1929): 12. http://www.dlib. si/?URN=URN:NBN:SI:DOC-AZUFNH9Q.

Mirk, Vasilij. »Še nekaj o Tržaški Glasbeni Matici«. Zbori 5, št. 4 (1929): 15-16. http://www.dlib.si/?URN=URN:NBN:SI:DOC-B38LDoGQ.

Nordio, Mario. Il XXV anniversario della fondazione del Conservatorio di musica Giuseppe Tartini. Trst: Conservatorio Tartini, 1929.

Radole, Giuseppe. Le scuole musicali a Trieste e il Conservatorio »G. Tartini«. Trst: Edizioni Italo Svevo, 1988.

Radole, Giuseppe. Ricerche sulla vita musicale a Trieste (1750-1950). Trst: Edizioni Italo Svevo, 1988

Radole, Giuseppe. Trieste, la musica e i musicisti (1945-1989). Trst: Edizioni Italo Svevo, 1992.

Rebula, Alojz. »Evropski moment v Gorici 1921: in memoriam Alojzij Res«. V La Mitteleuropa negli anni Venti: Culturà e società, ur. Quirino Principe. Videm: Istituto per gli incontri culturali mitteleuropei, atti del XXIII convegno, 1992.

Ribičič, Josip. Moja mlada leta. Ljubljana: Mladinska knjiga, 1965.

Rojc, Aleksander. Cultura musicale degli Sloveni a Trieste. Trst: ZTT, 1978.

Ruffini, Mario. Luigi Dallapiccola. Milano: Suvini Zerboni, 1999.

Slivnik, Francka, Ivo Svetina, ur. Josip Rijavec (189o-1959): slovenski tenorist mednarodnega slovesa. Ljubljana: Slovenski gledališki muzej, 2006.

Šantel, Saša. »Med barvami in glasbo«. V: Avgusta Šantel st., Avgusta Šantel ml., Saša Šantel, Življenje v lepi sobi, 129-211. Ljubljana: Nova revija, 2006.

Tuma, Henrik. Iz mojega življenja. Ljubljana: Založba Tuma, 1997. 